\title{
Tariff Planning in Urban Bus Transportation for Pristina
}

\author{
Bashkim Çerkini' ${ }^{1}$, Thoma Mitre ${ }^{2}$ \\ ${ }^{1}$ KBR, Cost Management - Project Control, Camp Bondsteel, Ferizaj, Kosovo \\ ${ }^{2}$ University of Tirana, Department of Applied Mathematics, Faculty of Natural Sciences, Tirana, Albania
}

\begin{abstract}
In this research paper we present the optimization of public urban transport network based on the techniques of applied mathematics and operational research. The efficiency of any public urban transport system can be enhanced by making a new design of urban bus transportation network with tariff zones for the Pristina city. Currently in urban bus transportation network in Pristina, there are no tariff zones and the ticket prices are set up arbitrarily. We will propose two designs of urban bus transportation network with tariff zones for Pristina city. We will find the new fares and will make comparison for operator incomes between two new designs and actual urban bus transportation network in Pristina city.
\end{abstract}

Keywords: Tariff Zones, Ticket Price, Urban Bus Transportation, Design and Operator Incomes.

\section{Introduction}

Ticket price is one of the most important issues in urban bus transportation. Projection of the tariff system in urban bus transportation is a very complex problem. When using a bus in urban bus transportation, a user usually has to pay ticket for his trip. There are several ways for defining prices for ticket in urban bus transportation. Unit tariff and zone tariffs are the most popular ones. In the tariff zone counting system the whole zone of the urban bus transportation network is divided into tariff zones.

In order to find out the ticket price for a trip, we should count the zones passed by the trip and make calculation based on the number of the passed zones. Changing tariff system in the Pristina City to a zone tariff system should be done in the way that the new system is still accepted by the passengers and does not decrease the income of the operator.

\section{Tariff Planning Zones}

We have introduced two models of tariff zones for the Pristina city. The first model consists of four (4) tariff zones and the second consists of three (3) tariff zones. In the maps below we have presented the main bus stations for simple calculation. These two proposed designs have different number of tariff zones and different partition structure, as seen in the figure 1 and 2 below:

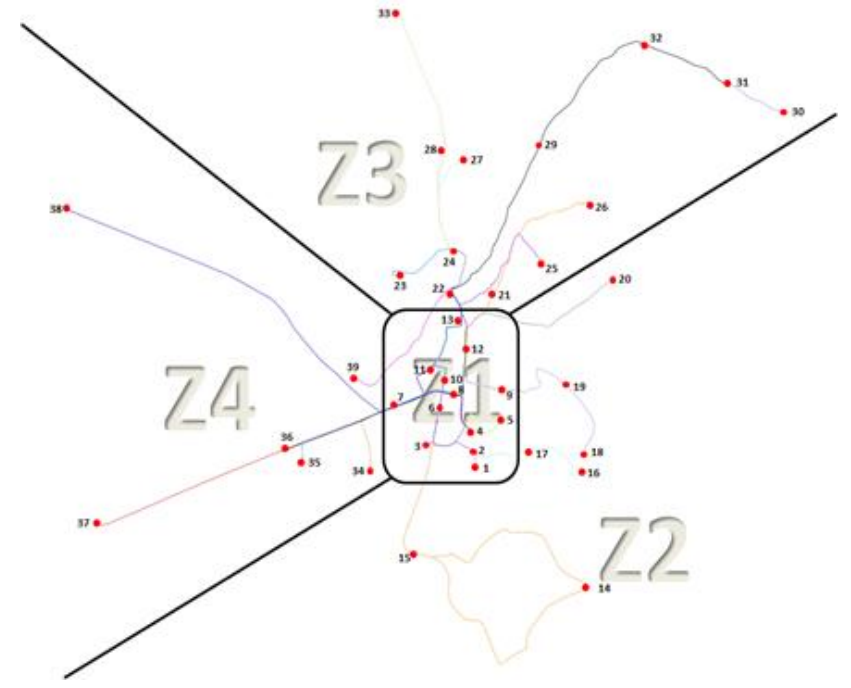

Figure 1: Design with four Tariff Zones

So let the partition zones $\mathrm{Z}=\left\{\mathrm{Z}_{1}, \mathrm{Z}_{2}, \mathrm{Z}_{3}\right.$ dhe $\left.\mathrm{Z}_{4}\right\}$. Suppose we have the same weights $\mathrm{W}_{\mathrm{uv}}=1$ for all $(\mathrm{u}, \mathrm{v}) \in \mathrm{V} \times \mathrm{V}$ referent prices $\mathrm{d}_{\mathrm{uv}}$ are given.

Optimal tariffs $c_{\max }^{*}(p)$ respective objective values $b_{\max }^{*}=b_{\max }\left(Z, c_{\max }^{*}\right)$ and $K_{\max }^{*}$ will be found using the following established formulas:

$$
\begin{aligned}
& c_{\text {max }}^{*}(p)=\frac{1}{2}\left(\max _{(u, v) \in M_{p}} d_{u v}+\min _{(u, v) \in M_{p}} d_{u v}\right) \\
& K_{\text {max }}^{*}(p)=\frac{1}{2}\left(\max _{(u, v) \in M_{p}} d_{u v}-\min _{(u, v) \in M_{p}} d_{u v}\right) \\
& b_{\text {max }}^{*}=\frac{1}{2} \max _{p=1, \ldots, L}\left(\max _{(u, v) \in M_{p}} d_{u v}-\min _{(u, v) \in M_{p}} d_{u v}\right)
\end{aligned}
$$

Now we find $c_{\max }^{*}(p), K_{\max }^{*}(p)$ and $b_{\max }^{*}(p)$ for zones $\mathrm{p}=$ 0,1 and 2 [4].

When the route is within one zone and not passed on to any other zones we do have:

\section{Volume 5 Issue 3, March 2016}




\section{International Journal of Science and Research (IJSR) \\ ISSN (Online): 2319-7064}

Index Copernicus Value (2013): 6.14 | Impact Factor (2014): 5.611

$c_{\max }^{*}(0)=0.40$

$K_{\max }^{*}(0)=0$

When the route passes between the two zones that's mean the route passes one tariff zone:

$c_{\max }^{*}(1)=0.45$

$K_{\max }^{*}(1)=0.05$

When road passes two tariff zones:

$c_{\max }^{*}(2)=0.45$

$K_{\max }^{*}(2)=0.05$

When road passes three tariff zones:

$c_{\max }^{*}(3)=0.45$

$K_{\text {max }}^{*}(3)=0.05$

Whereas the corresponding objective values $b_{\max }^{*}=0.05$ is the same for all cases crossings tariff zones.

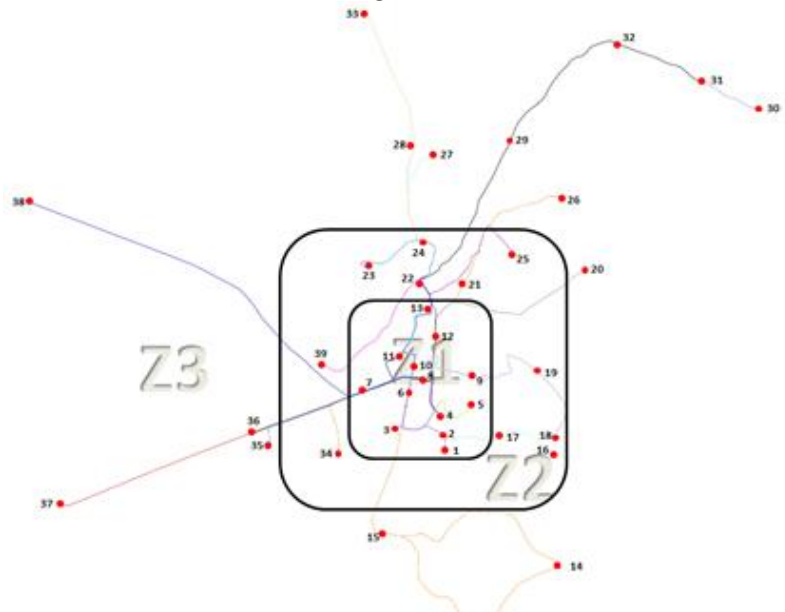

Figure 2: Design with three Tariff Zones

We have the same results in the case of division into three tariff zones with different structure and therefore we have:

$c_{\max }^{*}(0)=0.40$

$K_{\max }^{*}(0)=0$

$c_{\max }^{*}(1)=0.45$

$K_{\max }^{*}(1)=0.05$

$c_{\max }^{*}(2)=0.45$

$K_{\text {max }}^{*}(2)=0.05$

$c_{\max }^{*}(3)=0.45$

$K_{\text {max }}^{*}(3)=0.05$

$b_{\text {max }}^{*}=0.05$

In this new system of charging the fare found through counting zones from origin to destination. For example, the ticket price for the trips within the zone will be 0.40 euro and where we pass one, two or three tariff zones then the ticket price will be 0.45 euros.

\section{Operator Incomes for two new designs and actual urban bus transportation network}

The number of passengers who use public urban transport in Pristina for each bus line is taken on the basis of a research department of Public Services in the Municipality of Pristina. Through these data's we have calculated the operator's income for the current network of public urban transport with current prices as follows:

$$
\mathrm{I}=\mathrm{N} * \mathrm{P}
$$

I - Operator Incomes

$\mathrm{N}$ - Number of passengers

$\mathrm{P}$ - Ticket Price.

Results for each line are presented in tabular form for the current model of public urban transport network without tariff zone (Table 1).

Table 1: Operator Incomes for Current Design of Public Urban Transport Network

\begin{tabular}{|c|c|c|c|}
\hline Lines & Ticket Price & Number of Passengers on Daily Bases & Operator Incomes \\
\hline 1 & $\epsilon 0.40$ & 4031 & C $1,612.40$ \\
\hline 2 & $\epsilon 0.40$ & 2531 & $\in 1,012,40$ \\
\hline 3 & c 0.40 & 2326 & C 930.40 \\
\hline $3 A$ & $c 0.40$ & 1811 & C 724.40 \\
\hline 3B & c 0.40 & 909 & C 363.60 \\
\hline 4 & C 0.40 & 1678 & C 671.20 \\
\hline 5 & c 0.40 & 1207 & C 482.80 \\
\hline 6 & C 0.40 & 536 & C 214.40 \\
\hline 6A & C 0.40 & 920 & C 368.00 \\
\hline 7 & $C 0.40$ & 1729 & C 691.60 \\
\hline $7 A$ & C 0.40 & 1576 & C 630.40 \\
\hline 78 & $c 0.40$ & 1542 & € 616.80 \\
\hline 8 & $\in 0.40$ & 314 & € 125.60 \\
\hline 9 & $\in 0.40$ & 480 & E 192.00 \\
\hline 10 & $\epsilon 0.50$ & 2922 & C $1,461.00$ \\
\hline \multicolumn{2}{|c|}{ Dally Total } & 24512 & C $10,097.00$ \\
\hline \multicolumn{2}{|c|}{ Annual Total } & $6,882,970$ & $\mathcal{C 2 , 8 3 5 , 2 3 7 . 6 0}$ \\
\hline
\end{tabular}

The number of passengers who use public urban transport in Pristina from 06:00 to 22:00 is 24,512 and operator incomes on daily bases are $€ 10,097.00$. The total number of passengers who use public urban transport in Pristina for one year is $6,882,970$ and operator incomes are $€ 2,835,237.60$ [3]. To calculate operator incomes for new design of urban transport network public tariff divided into three zones, we have the following formula:

$\mathrm{I}=\mathrm{N}(0) * \mathrm{P}(0)+\mathrm{N}(1) * \mathrm{P}(1)+\mathrm{N}(2) * \mathrm{P}(2)+\mathrm{N}(3) * \mathrm{P}(3)$

I - Operator incomes

$\mathrm{N}(\mathrm{n})$ - The number of passengers passing $\mathrm{n}$ - tariff zones on their way

$\mathrm{P}(\mathrm{n})$ - The ticket price for $\mathrm{n}$ - tariff zones on their way.

Table 2: Operator Incomes for Digital Public Urban Transport Network with Three Tariff Zones

\begin{tabular}{|c|c|c|c|c|c|c|}
\hline \multirow[t]{2}{*}{ Lines } & \multirow[t]{2}{*}{$\begin{array}{l}\text { Number of } \\
\text { Passengers }\end{array}$} & \multicolumn{4}{|c|}{ Number of Passengers that Pass $n$-Tariff Zones on Dally Bases } & \multirow[b]{2}{*}{$\begin{array}{l}\text { Operator } \\
\text { Income }\end{array}$} \\
\hline & & O Zones $(\mathrm{C0.40)}$ & 1 Zone $(60.45)$ & 2 Zones $(C 0.45)$ & 3 Zones (C0.45) & \\
\hline 1 & 4031 & 4031 & 0 & 0 & 0 & C $1,612,40$ \\
\hline 2 & 2531 & 230 & 24 & 2277 & & C $1,127.45$ \\
\hline 3 & 2326 & 500 & 1646 & 180 & & $C 1,021.70$ \\
\hline $3 \mathrm{~A}$ & 1811 & 250 & 822 & 700 & 39 & C802,45 \\
\hline 3в & 909 & 225 & 609 & 75 & 0 & € 397.80 \\
\hline 4 & 1678 & 800 & 378 & 500 & & C 715.10 \\
\hline 5 & 1207 & 700 & 507 & 0 & & C 508.15 \\
\hline 6 & 536 & 400 & 100 & 36 & & $<221.20$ \\
\hline 6A & 920 & 380 & 515 & 25 & 0 & C 395.00 \\
\hline 7 & 1729 & 600 & 529 & 600 & & $<748.05$ \\
\hline $7 \mathrm{~A}$ & 1576 & 781 & 795 & 0 & 0 & C 670.15 \\
\hline 78 & 1542 & 300 & 372 & 826 & 44 & C 678.90 \\
\hline 8 & 314 & 160 & 154 & 0 & 0 & C 133.30 \\
\hline 9 & 480 & 291 & 140 & 20 & 29 & C 201.45 \\
\hline 10 & 2922 & 2200 & 722 & 0 & 0 & C $1,204,90$ \\
\hline Dally Total & 24512 & & & & & C $10,438.00$ \\
\hline Annual Total & 6882970 & & & & & C $2,930,990.40$ \\
\hline
\end{tabular}




\section{International Journal of Science and Research (IJSR) \\ ISSN (Online): 2319-7064}

Index Copernicus Value (2013): 6.14 | Impact Factor (2014): 5.611

With the applying of new design of public urban transport network divided into three tariff zones so the operator incomes on daily basis from sold tickets are $€ 10,438.00$ while the total annual incomes of the operator is $€ 2,930,990.40$.The calculating of the operator incomes of the design of public urban transport network divided into four tariff zones, has same results and follows the same procedure as the design of public urban transport divided in three tariff zones, presented in tabular forms as follows.

Table 3: Operator Incomes for Design of Urban Public Transport Network with Four Tariff Zones

\begin{tabular}{|c|c|c|c|c|c|c|}
\hline \multirow[t]{2}{*}{ Unes } & \multirow{2}{*}{$\begin{array}{l}\text { Number of } \\
\text { Passengers }\end{array}$} & \multicolumn{4}{|c|}{ Number of Passengers that Pass $n$-Tariff Zones on Daily Bases } & \multirow[b]{2}{*}{$\begin{array}{l}\text { Operator } \\
\text { Income }\end{array}$} \\
\hline & & 0 Zones $(\boldsymbol{C} 0.40)$ & 1 Zone $(60.45)$ & ) 2Zones $(0.45)$ & 3 Zones $(60.45)$ & \\
\hline 1 & 4031 & 4031 & 0 & 0 & & C $1,612.40$ \\
\hline 2 & 2531 & 253 & 2278 & 0 & & $<1,126,30$ \\
\hline 3 & 2326 & 230 & 2096 & 0 & & C $1,035.20$ \\
\hline $3 A$ & 1811 & 950 & 861 & 0 & & 6767.45 \\
\hline 3B & 909 & 300 & 609 & 0 & & C 394.05 \\
\hline 4 & 1678 & 800 & 878 & 0 & & C 715.10 \\
\hline 5 & 1207 & 600 & 607 & 0 & & C513.15 \\
\hline 6 & 536 & 200 & 100 & 236 & & C 231.20 \\
\hline 6A & 920 & 400 & 415 & 105 & & C 394.00 \\
\hline 7 & 1729 & 800 & 900 & 29 & & C738.05 \\
\hline $7 A$ & 1576 & 781 & 795 & 0 & & C 670.15 \\
\hline 78 & 1542 & 720 & 372 & 450 & & C 657.90 \\
\hline 8 & 314 & 114 & 200 & 0 & & $C_{135.60}$ \\
\hline 9 & 480 & 320 & 140 & 20 & & C 200.00 \\
\hline 10 & 2922 & 2200 & 722 & 0 & & $(1,204,90$ \\
\hline Daily Total & 24512 & & & & & C $10,395.45$ \\
\hline Annual Total & 6882970 & & & & & C2,919,042,36 \\
\hline
\end{tabular}

With the applying of new design of the urban public transport network that is divided into four tariff zones so the operator incomes on a daily basis from sold tickets are $€ 10,395.45$ and total annual operator incomes is $€ 2,919,042.36$. Comparison between the operator incomes on a daily basis and annual total operator incomes for the three network designs is shown in the tables 2 and 3 and diagrams on figures 3 and 4 .

Table 4: Operator Incomes on Daily Basis

\begin{tabular}{|l|ll|}
\hline \multicolumn{4}{|c|}{ Daily Incomes on Daily Bases } \\
\hline Actual Model without Tariff Zones & $€$ & 10,097 \\
Model with 3 Tariff Zones & $€$ & 10,438 \\
Model with 4 Tariff Zones & $€$ & 10,395 \\
\hline
\end{tabular}

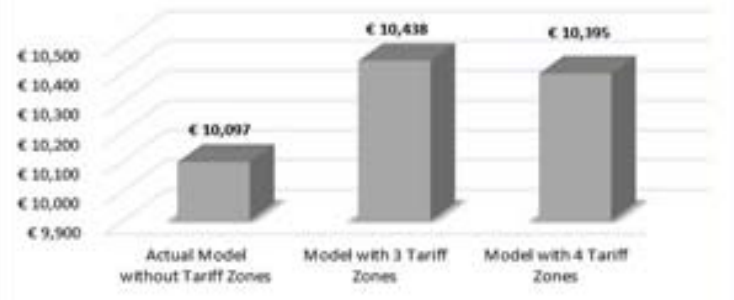

Figure 3: Diagram of Operator Incomes on Daily Basis

Table 5: Operator Annually Incomes

\begin{tabular}{|l|l|}
\hline \multicolumn{3}{|c|}{ Annual Incomes on Daily Bases } \\
\hline Actual Model without Tariff Zones & $€ 2,835,238$ \\
\hline Model with 3 Tariff Zones & $€ 2,930,990$ \\
Model with 4 Tariff Zones & $€ 2,919,042$ \\
\hline
\end{tabular}

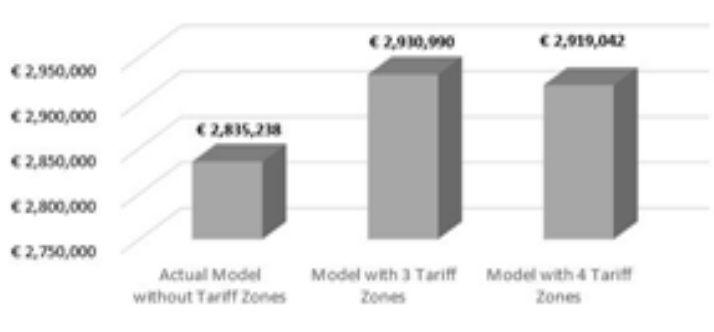

Figure 4: Diagram of Operator Annually Incomes

\section{Conclusion}

This research is based on the real data about passengers' trips from Pristina Municipality. Based on the results shown in tables and diagrams above, we conclude that operator incomes are almost equal among two new designs with three and four tariff zones. Operator incomes for both new designs with tariff zones are slightly higher than the current urban bus transportation network which is without tariff zones. Public urban transport design with zoning tariff is being applied in most of the world's metropolises and is correct and fair for passenger and operator. Ticket fare system based on the counting zone tariffs should be applied in Pristina city because that is much more practical and fair for passengers and operators.

\section{References}

[1] Michal K., Exact Approach to the Tariff Zones Design Problem in Public Transport,

[2] Mitre Th., Godolja M., Spaho A., Matematika e Zbatuar (Ushtrime),

[3] Municipality of Pristina, Department of Public Services, Protection and Rescue,

[4] Schöbel A., Optimization in Public Transportation (2004).

\section{Author Profile}

Bashkim Çerkini has received the Master Degree in University of Business and Technology (UBT) in Pristina, Kosovo in 2011. He is a PhD Candidate in University of Tirana, Department of Applied Mathematics, Faculty of Natural Sciences, Tirana - Albania.

Thoma Mitre is Professor in Faculty of Natural Sciences, Department of Applied Mathematics in University of Tirana, Albania. 